\title{
THE COMPLETE AMINO ACID SEQUENCE OF COPPER, ZINC SUPEROXIDE DISMUTASE FROM SACCHAROMYCES CEREVISIAE
}

\author{
by \\ JACK T. JOHANSEN, CARSTEN OVERBALLE-PETERSEN, BRIAN MARTIN, \\ VILLY HASEMANN and IB SVENDSEN \\ Department of Chemistry, Carlsberg Laboratory, \\ Gamle Carlsberg Vej 10, DK-2500 Copenhagen Valby
}

Keywords: Superoxide dismutase, amino acid sequence, Saccharomyces cerevisiae

The amino acid sequence of the copper,zinc superoxide dismutase from Saccharomyces cerevisiae has been determined by automated Edman degradation. Peptides were obtained from cyanogen bromide cleavage, Staphylococcus aureus V8 protease digestion, tryptic and chymotryptic digests of the citraconylated reduced and carboxymethylated enzyme, and by further fragmentation of selected peptides with trypsin. From the alignment of these peptides and the previously published sequence of the first 54 amino terminal residues (24) the complete sequence was deduced by direct sequence identification of all 153 amino acid residues and of all peptide overlaps. The amino acid sequence corresponds to a molecular weight of 15.950 for each of the two identical subunits in the native enzyme. The primary structure of yeast copper, zinc superoxide dismutase is $55 \%$ identical with the sequence of the copper, zinc enzyme from bovine erythrocytes. Importantly, all the copper and zinc ligands, six histidine residues and one aspartate residue from the bovine enzyme, are conserved in the yeast enzyme. The high overall sequence homology and conservation of important metal binding active site amino acid residues suggest that the three-dimensional structure and in particular the active site geometry is virtually the same for the bovine and yeast enzyme. In contrast no sequence homology is apparent by comparison with the manganese or iron class of superoxide dismutases indicating that the two classes have not evolved from a common ancestor.

\footnotetext{
Abbreviations: $\mathrm{SOI})=$ superoxide dismutase, $\mathrm{DPCC}=$ diphenylcarbamylchloride, $\mathrm{CM}=$ carboxymethyl, $\mathrm{DE}$ $=$ diethylaminoethyl, THEED $=\mathrm{N}, \mathrm{N}, \mathrm{N}^{\prime}, \mathrm{N}^{\prime}$-tetrakis (2-hydroxyethyl) ethylene diamine, polybrene $=1,5$ dimethyl-1,5-diazaundecamethylene polymethobromide. $\mathrm{PTH}=$ phenylthiohydantoin, DMAA = dimethyl allylamine, HPLC $=$ high performance liquid chromatography, TLC $=$ thin layer chromatography, PMSF $=$ phenylmethane sulfonyl fluoride, n.m.r. = nuclear magnetic resonance.
} 


\section{INTRODUCTION}

Superoxide dismutases (SOD) are a group of metalloenzymes, whose function is to scavenge the superoxide radical anion $0 \overline{2}(12)$ by catalyzing its dismutation to hydrogen peroxide and dioxy. gen:

$$
2 \mathrm{O}_{2}^{-}+2 \mathrm{H}^{+} \rightarrow \mathrm{H}_{2} \mathrm{O}_{2}+\mathrm{O}_{2}
$$

thus affording the organism protection against the toxic effect of this free radical (23).

Apart from a few exceptions the enzymes isolated from procaryotes and eucaryotic mitochondria contain either manganese or iron (15) and comparative amino acid sequence studies on the N-terminal regions reveal a substantial homology among the enzymes from a wide variety of sources (15). In contrast the cytoplasmic enzymes isolated from eucaryotes usually contain copper and zinc, but only limited amino acid sequence data are available for this group of enzymes. In 1974 Steinman et al. (28) reported the complete amino acid sequence of bovine $\mathrm{Cu}$, $\mathrm{Zn}$ superoxide dismutase. Furthermore, RICHARDSON et al. (25) have reported the crystal structure to $3 \AA$ resolution for this enzyme. The only other available sequence data from this group of superoxide dismutases are the partial amino acid sequences of the enzymes from Saccharomyces cerevisiae (24) and from human erythrocytes (2).

In view of the recent interest in superoxide dismutase from an evolutionary standpoint (15, 27) and as part of a study of the structurefunction relationships of these enzymes $(6,7)$, we report in the present work the complete amino acid sequence of the $\mathrm{Cu}, \mathrm{Zn}$ superoxide dismutase from Saccharomyces cerevisiae.

To obtain the desired peptides for the elucidation of the primary structure, the following methods were employed. 1. cyanogen bromide cleavage at the single methionine residue. 2 . tryptic cleavage at the arginine residues after appropriate blockage of the lysine residues and 3. scission at the glutamic acid residues by $\mathbf{S}$. aureus protease.

\section{MATERIALS AND METHODS}

\subsection{Materials}

Yeast $\mathrm{Cu}, \mathrm{Zn}$ superoxide dismutase was isolated as described by Petersen et al. (24).
S. aureus (strain V8) protease was a product of Miles laboratories Ltd., Stokes Poges, England. DPCC-trypsin, chymotrypsin $(3 \times$ crystallized), and carboxypeptidase A and B were purchased from Sigma Chemical Company, St. Louis, Mo., U.S.A. Carboxypeptidase Y was from the United Breweries, Copenhagen, Denmark.

Microgranular CM-52 cellulose and DE-52 cellulose were from Whatman Biochemicals, Maidstone, England. Sephadex gels were products of Pharmacia Fine Chemicals, Uppsala, Sweden.

For sequence determinations the following chemicals were employed: $\mathrm{N}, \mathrm{N}, \mathrm{N}^{\prime}, \mathrm{N}^{\prime}$-tetrakis (2hydroxyethyl) ethylene diamine (THEED) was obtained from ICN-K\&K Laboratories Inc., Plainview, New York, and used without further purification. Ethyl acetate (UV solvent grade) was purchased from Merck Chemicals, West Germany. Both THEED and ethyl acetate were found to be free of aldehydes as determined by the Tollens' reaction (11). Polybrene, phenylisothiocyanate, heptane, heptafluorobutyric acid, propanol, trifluoroacetic acid, butyl chloride, benzene and $1 \mathrm{~m}$-Quadrol were all Sequanal grade reagents from Pierce Chemicals, Rockford, Ill., U.S.A. The 0.1 M-THEED used as the coupling buffer in place of $1 \mathrm{M}$-Quadrol and the ethyl acetate containing 15\% 1-propanol were prepared according to the procedure described by BegG and Morgan (3).

All other chemicals were analytical grade. Distilled water was used throughout.

\subsection{Amino acid sequence determination}

Automatic sequence analysis was performed using a Beckman $890 \mathrm{C}$ sequencer by the method of Edman and Begg (10). Procedures supplied with the instrument were essentially followed. However, reagent $\mathrm{R}_{2}$ was $0.1 \mathrm{M}-$ THEED replacing $1.0 \mathrm{~m}$-Quadrol and the $\mathrm{S}_{2}$ wash was ethyl acetate, $15 \%$ in propanol and $0.1 \%$ in acetic acid (3). The Beckman program 122974 (single cleavage, fast protein Quadrol) was used throughout the analyses but with the time for the $S_{2}$ wash reduced from 600 to 400 seconds in step 29.

All samples were applied to the cup dissolved in $30 \%$ acetic acid and then dried using the Beckman Sample Application Subroutine (Pro- 
gram 02772). In the case of peptides, smaller than 30 residues, $100 \mu \mathrm{l}$ of polybrene (30 $\mathrm{mg} \cdot \mathrm{ml}^{-1}$ in $\mathrm{H}_{2} \mathrm{O}$ ) was added to the sample as suggested by $T_{A R R}$ et al. (29). In contrast to TARR et al., we have not experienced any problem with polybrene in our identification of the PTHderivative in Step 1 and hence we have omitted the dummy step as recommended by these authors. This difference is propably due to the fact that we are not using the $»$ DMAA peptide program « and that in our program the $S_{2}$ wash of the peptide film removes the excess reagent prior to the butyl chloride extraction of the 2anilino-5-thiazolinone amino acid residue in Step 1.

Conversion to the PTH-amino acids was performed according to a published procedure (11), and the PTH-amino acids were identified by a combination of at least two of the following methods: a) high performance liquid chromatography $(24)$, b) thin layer chromatography (21), c) back-hydrolysis to free amino acid (22), d) identification of histidine with Pauly's reagent (11) and of arginine with phenanthroquinone (16).

HPLC identifications were made using a Hewlett-Packard 1084 A chromatograph equipped with an RP-8, $10 \mu \mathrm{m}$ reverse phase column. A gradient elution system was employed starting with $0.01 \mathrm{~m}$-sodium acetate $\mathrm{pH} 4.0$ containing $10 \%$ acetonitrile as initial eluant, and pure acetonitrile as second eluant at a flow rate of 3.0. $\mathrm{ml} \cdot \mathrm{min}^{-1}$. HPLC was used predominantly for identification, since all PTH-amino acids with the exception of PTH-valine and PTH-methionine were clearly separated and identified. Repetitive yields were calculated from the quantitative recovery of the PTH-amino acids by HPLC. Identification of valine and methionine were made by both TLC and back-hydrolysis.

TLC on $7.5 \times 7.5 \mathrm{~cm}$ polyamide sheets was performed as described by KuLBE (21).

Back-hydrolysis to the parent amino acid was done at $150^{\circ} \mathrm{C}$ for four hours using $5.7 \mathrm{M}-\mathrm{HCl}$ containing $0.1 \% \mathrm{SnCl}_{2}(22)$.

Carboxyl terminal sequence analysis was performed using carboxypeptidase $\mathrm{Y}, \mathrm{B}$ or $\mathrm{A}$. Digestion of peptides with carboxypeptidase $\mathrm{Y}$ was carried out in $0.2 \mathrm{M}-2$ (N-morpholino)ethanesulfonic acid-buffer at $\mathrm{pH}$ 's between 5 and 7 at $22{ }^{\circ} \mathrm{C}$, while that with carboxypeptidase
$\mathrm{B}$ was carried out in $0.2 \mathrm{M}-\mathrm{N}$-ethylmorpholine/ acetic acid buffer $\mathrm{pH} 8.0$ at $22^{\circ} \mathrm{C}$ (1). The peptide-enzyme ratios were approximately 100:1 and 10:1 (w/w) for carboxypeptidase $Y$ and $B$, respectively. In either method norleucine was added as an internal standard. At predetermined time intervals $50 \mu \mathrm{l}$ aliquots of the digest were added to $50 \mu \mathrm{l}$ of $0.2 \mathrm{M}-\mathrm{HCl}$ to stop the reaction. The solutions were then dried in a stream of air at $37^{\circ} \mathrm{C}$, and the free amino acids determined directly by amino acid analysis.

\subsection{Amino acid analysis}

The amino acid composition of the enzyme was determined by hydrolysis of duplicate samples in $5.7 \mathrm{M}-\mathrm{HCl}$, in vacuo, at $110^{\circ} \mathrm{C}$ for 24,48 and 96 hours. The amino acid analyses were performed on a Durrum D-500 amino acid analyzer. The values for serine and threonine were obtained by extrapolation to zero time, whereas the values for valine and isoleucine were obtained after 96 hours of hydrolysis. Halfcystine was determined as cysteic acid after performic acid oxidation of the enzyme employing the procedure described by Hirs (18). Amino acid analyses of peptides were performed on samples hydrolyzed for 24 hours and are not corrected for either partial destruction of serine and threonine during hydrolysis or for incomplete liberation of valine and isoleucine. Halfcystine in peptides was determined as $\mathrm{S}$ carboxymethyl cysteine. All results are expressed as molar ratios. In the chromatographic procedure employed, asparagine and glutamine both co-eluted with serine and therefore in the case of carboxypeptidase hydrolysis experiments the actual amino acid was identified by dansylation of a duplicate sample and separation of the resulting dansylated amino acids on polyamide sheets (31). Yields of peptides are based upon amino acid analyses.

\subsection{Reduction and S-carboxymethylation of SOD}

Reduction and S-carboxymethylation were carried out as described by WAXDAL et al. (30). Typically, $60 \mathrm{mg}$ ( 3.8 umoles of subunit) of SOD were dissolved in $6 \mathrm{ml}$ of $0.5 \mathrm{M}$-Tris- $\mathrm{HCl}$ buffer pH 9.0, containing $0.002 \mathrm{M}$-ethylenediamine tetraacetate, and $6 \mathrm{~m}$-guanidine hydrochloride. The solution was purged with a stream of $\mathrm{N}_{2}$ for 10 
minutes, and $33 \mathrm{mg}(213 \mu$ moles $)$ of dithiothreitol was added. After 20 hours of reduction at room temperature in the dark, the $\mathrm{pH}$ was adjusted to 8.1 with $6 \mathrm{M}-\mathrm{HCl}$ and $100 \mathrm{mg}$ iodoacetic acid was added. The $\mathrm{pH}$ was maintained at 8.1 by dropwise addition of $2 \mathrm{M}$ $\mathrm{NH}_{4} \mathrm{OH}$. After 20 minutes of reaction, the reduced S-carboxymethylated product was dialyzed against $0.1 \mathrm{M}$-ammonium acetate $\mathrm{pH} 5.0$ and finally lyophilized.

\subsection{Preparation and fractionation of cyanogen bromide peptides of SOD}

The native enzyme ( $60 \mathrm{mg}, 3.8 \mu$ moles) were dissolved in $7 \mathrm{ml}$ of $70 \%$ formic acid, and 100 $\mathrm{mg}$ of cyanogen bromide was added to the solution. After 24 hours at room temperature in the dark and under $\mathrm{N}_{2}(20)$ the reaction mixture was diluted with 10 volumes of distilled water and lyophilized. The CNBr-treated protein was then reduced and S-carboxymethylated as described in section 2.4 .

The CNBr-peptide mixture was dissolved in $0.01 \mathrm{M}$-Tris-HCl buffer $\mathrm{pH} 7.0$ and the peptides fractionated on a column of DE-52 cellulose. The pooled peptide fractions were lyophilized and salt was removed by buffer exchange on a column of Sephadex G-10 $(2.6 \times 40 \mathrm{~cm})$ equilibrated and eluted with $0.01 \mathrm{M}$-ammonium bicarbonate, $\mathrm{pH}$ 7.8. Subsequently, the peptides were recovered after freeze drying.

\subsection{S. aureus protease digestion of \\ S-carboxymethylated SOD}

One hundred $\mathrm{mg}$ ( $6.3 \mu \mathrm{moles})$ of S-carboxymethylated SOD were dissolved in $10 \mathrm{ml} 0.1 \mathrm{~m}$ ammonium bicarbonate, $\mathrm{pH} 7.8$ and digested with $2 \mathrm{mg}$ of S. aureus protease for 24 hours at room temperature (19). The digestion was terminated by addition of excess PMSF (14). The peptide mixture was first subjected to gel filtration on a column of Sephadex G-25 superfine. Peptide containing fractions were located using the o-phthalaldehyde fluorescent reaction (4) and by the absorbance at $280 \mathrm{~nm}$. Further purification of peptides was achieved by chromatography on DE-52 cellulose and subsequently on CM-52 cellulose. The pooled fractions were desalted as described in section 2.5.

\subsection{Tryptic digestion of S-carboxymethylated SOD and peptides}

Restricted tryptic cleavage at arginyl peptide bonds was achieved by reversible blocking of lysyl side chains with citraconic anhydride $(5,9)$. One hundred $\mathrm{mg}(6.3 \mu$ moles $)$ of S-carboxymethylated SOD were citraconylated. The product was dissolved in $10 \mathrm{ml}$ of $0.1 \mathrm{M}$-ammonium bicarbonate buffer, $\mathrm{pH} 8.0$ and digested with 1 mg DPCC-treated trypsin for 6 hours. The reaction was stopped by addition of an excess of PMSF. The citraconyl groups were removed by adjusting the $\mathrm{pH}$ to 3.5 with $1 \mathrm{M}$-acetic acid and then incubating the peptide mixture for 18-22 hours at $4{ }^{\circ} \mathrm{C}$. The resulting peptide mixture was fractionated on a column of Sephadex G-50 and the peptides further fractionated on a column of DE-52 cellulose.

The $\mathrm{N}$-terminal $\mathrm{CNBr}$ fragment, $\mathrm{F}_{\mathrm{N}}$, was also subjected to restricted tryptic cleavage. One $\mu$ mole of $F_{N}$ was dissolved in $5 \mathrm{ml}$ of $3 \mathrm{M}$ -guanidine hydrochloride (carbonate buffer $\mathrm{pH}$ 9.0), $250 \mathrm{mg}$ citraconic anhydride was added and the $\mathrm{pH}$ maintained between 8.5 and 9.0 by the addition of $6 \mathrm{~m}-\mathrm{NaOH}$. The citraconylated $\mathrm{F}_{\mathrm{N}}$ peptide was passed over a column of Sephadex G-25 equilibrated with 0.01 M-ammonium bicarbonate buffer, $\mathrm{pH} 7.8$, and lyophilized. The peptide was dissolved in $5 \mathrm{ml}$ of $0.1 \mathrm{M}$ ammonium bicarbonate buffer, $\mathrm{pH} 7.8$ and digested with $1 \mathrm{mg}$ of DPCC-treated trypsin for 8 hours at room temperature. The reaction was terminated by the addition of an excess of PMSF. The peptide mixture was fractionated on Sephadex G-25. Before the peptides were subjected to automatic sequence analysis the citraconyl groups were removed as described above.

The peptide SP-10 was similarly digested with DPCC-treated trypsin after blocking the aminoterminal residue and the lysyl side chains with dansyl chloride (31).

\subsection{Chymotryptic digestion of S-carboxymethylated SOD}

Twenty mg (1.3 $\mu$ moles) of S-carboxymethylated SOD were dissolved in $2.5 \mathrm{ml} 0.1 \mathrm{M}-\mathrm{KCl}$ and digested with $120 \mu \mathrm{g}$ chymotrypsin at $\mathrm{pH}$ 8.2 and $25^{\circ} \mathrm{C}$ using a Radiometer TTT60 pH stat and $0.05 \mathrm{M}-\mathrm{NaOH}$ as titrant. When the initial rapid base uptake ceased an excess of PMSF was added to block the chymotryptic 
activity. The peptide mixture was fractionated on Biogel P-10 with $30 \%$ acetic acid as eluant. The peptide containing fractions were located both by absorbance at $280 \mathrm{~nm}$ and by reaction with ninhydrin after alkaline hydrolysis of aliquots from the fractions (17).

\subsection{Peptide nomenclature}

The two $\mathrm{CNBr}$-fragments are designated $\mathrm{F}_{\mathrm{N}}$ and $\mathrm{F}_{\mathrm{C}}$ corresponding to the $\mathrm{N}$-terminal and $\mathrm{C}$ terminal fragment, respectively. The tryptic peptides are numbered $T-1$ to $T-5$, the numbering is done according to the order in which they occur in the protein starting from the $\mathrm{N}$-terminal end. Similarly, peptides resulting from S. aureus protease digestion are numbered SP-1 to SP-10. Chymotryptic peptides of interest are designated $\mathrm{C}_{\mathrm{a}}$ and $\mathrm{C}_{b}$ indicating that the two peptides are present in the same peptide pool. After peptide SP-10 was further digested with trypsin, the peptide of interest is numbered SP-10-T.

\section{RESULTS}

The amino acid composition of SOD (Table I) established that the subunit polypeptide chain consisted of approx. 150 amino acid residues. We have previously reported the amino acid sequence of 52 of the first 54 amino acid residues (residues No. 43 and No. 47 were not identified) of the $\mathrm{N}$-terminal sequence of yeast superoxide dismutase (24) corresponding to approx. 1/3 of the entire sequence. To establish the complete amino acid sequence we employed chemical and enzymatic cleavage procedures which resulted in predominantly large peptide fragments (15-40 residues) suitable for automatic Edman degradations. Thus, Sephadex G-25 or G-50 chromatography was always performed as the initial fractionation method to separate large and small peptides. Subsequent purification was achieved by ion exchange chromatography on DE-52 cellulose and/or CM-52 cellulose.

\subsection{Cyanogen bromide peptides of S-carboxymethylated SOD}

Cleavage of the single methionyl bond of SOD by cyanogen bromide yielded two fragments. Amino acid analysis showed $90 \%$ cleavage of the methionyl peptide bond. After reduction and S-carboxymethylation, fractionation of the peptide mixture on Sephadex G-50 gave a single peak suggesting that the methionine residue was situated in the middle of the peptide chain thus resulting in fragments of similar sizes. Fractionation was achieved by chromatography on a column of DE-52 cellulose (Figure 1). Amino acid analyses of peak I, II and III exhibited identical results. Similarly, the amino acid composition of peak V, VI and VII was also identical, whereas the amino acid composition of peak IV corresponded to uncleaved SOD. Since the peptides in pool V, VI and VII contained the single tyrosine residue in the molecule, which we previously have shown to be located at position 32 in the N-terminal sequence (24), these peaks contain the $\mathrm{N}$-terminal cyanogen bromide fragment, $F_{N}$. This fragment contains a $C$-terminal homoserine or its lactone, which most probably explain the presence of the same fragment in the two major peaks $\mathrm{V}$ and VI. The presence of a small amount of the same fragment in peak VII is not clear, but could be due to incomplete Scarboxymethylation. The amino acid composition of $F_{N}$ (Table I) showed that it consisted of approx. 84 residues (residues 1 through 84). Since the sequence of the first 55 residues was

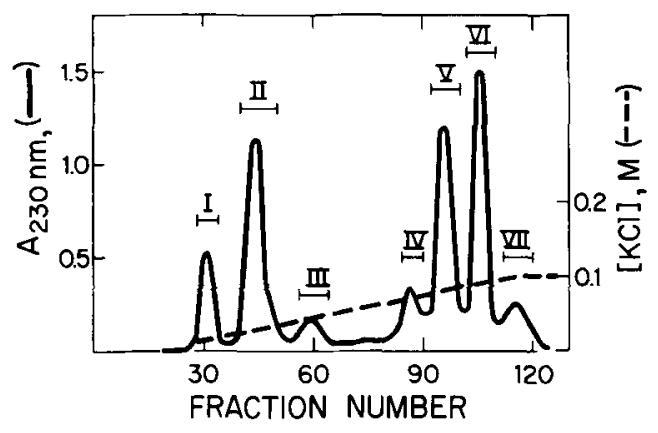

Figure 1. Fractionation of cyanogen bromide peptides of S-carboxymethylated SOD on a $1.6 \times 15 \mathrm{~cm}$ column of DE-52 equilibrated with 0.01 M-Tris$\mathrm{HCl}, \mathrm{pH}$ 7.0. Following the passage of approx. 100 $\mathrm{ml}$ of the equilibration buffer, the column was eluted with a linear gradient of $\mathrm{KCl}$ from $0.0-0.1 \mathrm{M}$, in the initial buffer. The flow rate was $30 \mathrm{ml} \cdot$ hour $^{-1}$ and fractions of $5.0 \mathrm{ml}$ were collected and pooled as indicated by horizontal bars. 
Table I

Amino acid composition of superoxide dismutase and cyanogen bromide peptides.

\begin{tabular}{|c|c|c|c|c|c|c|c|}
\hline \multirow[b]{2}{*}{ Amino acid } & \multirow{2}{*}{$\frac{\text { SOD }}{\text { AAA }^{b)}}$} & \multicolumn{2}{|c|}{$\mathrm{F}_{N^{a}}{ }^{a}$} & \multicolumn{2}{|c|}{$\mathrm{F}_{\mathrm{C}^{\mathrm{al}}}$} & \multicolumn{2}{|c|}{$\mathrm{F}_{\mathrm{i}}+\mathrm{F}_{\mathrm{C}}^{\mathrm{a}}$} \\
\hline & & AAA & $\mathrm{SEQ}^{\mathrm{c})}$ & AAA & SEQ & AAA & SEQ \\
\hline Aspartic acid & 16.8 & 8.0 & 8 & 9.0 & 9 & 17.0 & 17 \\
\hline Threonine & $9.8^{\mathrm{d})}$ & 4.9 & 5 & 4.9 & 5 & 9.8 & 10 \\
\hline Serine & $10.6^{\mathrm{d})}$ & 5.5 & 6 & 4.7 & 5 & 10.2 & 11 \\
\hline Glutamic acid & 13.3 & 8.5 & 9 & 3.7 & 4 & 12.2 & 13 \\
\hline Proline & 7.9 & 4.8 & 5 & 2.8 & 3 & 7.6 & 8 \\
\hline Glycine & 21.5 & 10.3 & 10 & 11.8 & 12 & 21.1 & 22 \\
\hline Alanine & 12.7 & 8.5 & 9 & 4.0 & 4 & 12.5 & 13 \\
\hline Valine & $16.4^{e)}$ & 8.7 & 10 & 5.5 & 7 & 14.2 & 17 \\
\hline Methionine & $0.9^{f)}$ & $0^{i)}$ & 1 & 0 & 0 & 0 & 1 \\
\hline Isoleucine & $5.5^{\mathrm{e})}$ & 1.7 & 2 & 3.3 & 4 & 5.0 & 6 \\
\hline Leucine & 6.1 & 1.3 & 1 & 5.3 & 5 & 6.6 & 6 \\
\hline Tyrosine & 1.0 & 1.0 & 1 & 0 & 0 & 1.0 & 1 \\
\hline Phenylalanine & $5.7^{e)}$ & 4.5 & 5 & 1.1 & 1 & 5.6 & 6 \\
\hline Histidine & 5.5 & 4.7 & 5 & 0.9 & 1 & 5.6 & 6 \\
\hline Lysine & $9.7^{\circ}$ & 4.1 & 4 & 6.0 & 6 & 10.1 & 10 \\
\hline Arginine & 4.0 & 1.9 & 2 & 1.9 & 2 & 3.8 & 4 \\
\hline Half-cystine & $1.8 \mathrm{~g})$ & $0.6^{\mathrm{h})}$ & 1 & $0.7^{\mathrm{hl}}$ & 1 & $1.3^{\mathrm{hl}}$ & 2 \\
\hline $\begin{array}{l}\text { Total number of } \\
\text { residues }\end{array}$ & & & 84 & & 69 & & 153 \\
\hline Yieldj) & & $64 \%$ & & $59 \%$ & & & \\
\hline
\end{tabular}

a) Duplicate samples hydrolyzed for 24 hours. b) AAA is amino acid analysis. c) SEQ is the amino acid composition calculated from the sequence. ${ }^{\text {d) }}$ extrapolated to zero time. e) value after 96 hours of hydrolysis. f) determined as methionine sulfone after performic acid oxidation. g) determined as cysteic acid after performic acid oxidation. h) determined as S-carboxymethylcysteine. ') homoserine lactone was not determined. j) calculated on the basis of $100 \%$ prior to $\mathrm{CNBr}$-cleavage.

already known from the previous sequence studies of the intact peptide chain (24) no further sequencing of this fragment was performed.

Fractionation of the $\mathrm{F}_{\mathrm{C}}$ fragment into three discrete peaks (Pool I, II and III) is not clear but might originate from partial deamidation or incomplete S-carboxymethylation. Sequence studies were only performed on the $F_{C}$ fragment isolated from peak II. The amino acid composition of $\mathrm{F}_{\mathrm{C}}$ (Table I) showed that the fragment contained 69 residues (residues 85 through 153). Since the sum of the amino acid compositions of $F_{X}$ and $F_{C}$ (Table $I$ ) is very similar to the composition found for SOD itself, presumably all amino acid residues of SOD are accounted for in $F_{X}$ and $F_{C}$.

Sequence analysis of $F_{C}$ was performed twice and in both runs, 35 steps of Edman degradations were successfully performed.
The result of the sequence analysis were as follows:

$$
\begin{aligned}
& 85 \quad 90 \\
& \text { Gly-Asn-Val-Lys-Ihr-Asp-Glu-Asn-Gly } \\
& 95 \quad 100 \\
& \text {-Val-Ala-Lys-Gly-Ser-Phe-Lys-Asp-Ser } \\
& 105 \\
& 110 \\
& \text {-Leu-Ile-Lys-Leu-Ile-Gly-Pro-Thr-Ser } \\
& 115 \\
& \text {-Val-Val-Gly- ? -Ser-Val-Val-Ile- }
\end{aligned}
$$

In both runs 200 nmoles of $\mathrm{F}_{\mathrm{C}}$ were subjected to degradation, and the average repetitive yields were $92 \%$ and $94 \%$ for run 1 and 2 , respectively. The residue at position 115 could not be determined with certainty, but showed a positive phenanthroquinone spot test for arginine. 


\subsection{S. aureus protease peptides of SOD}

Peptides, obtained by $\mathrm{S}$. aureus protease cleavage of S-carboxymethylated SOD, were fractionated on a Sephadex G-25 column as shown in Figure 2A. Since only large peptides suitable for automated sequence analysis were of interest, pool I was further purified on a DE-52 cellulose ion-exchange column utilizing a $\mathrm{KCl}$ gradient. The elution profile of this column is shown in Figure 2B. Amino acid analyses (Table II) and preliminary sequence analyses, (viz. one to two cycles of Edman degradation) revealed that pool II and pool IV (Figure 2B) contained pure fragments corresponding to peptide SP-8 and SP-7, respectively. Pool I and pool III (Figure 2B) were not pure and hence pool I was further purified by ion exchange chromatography on a

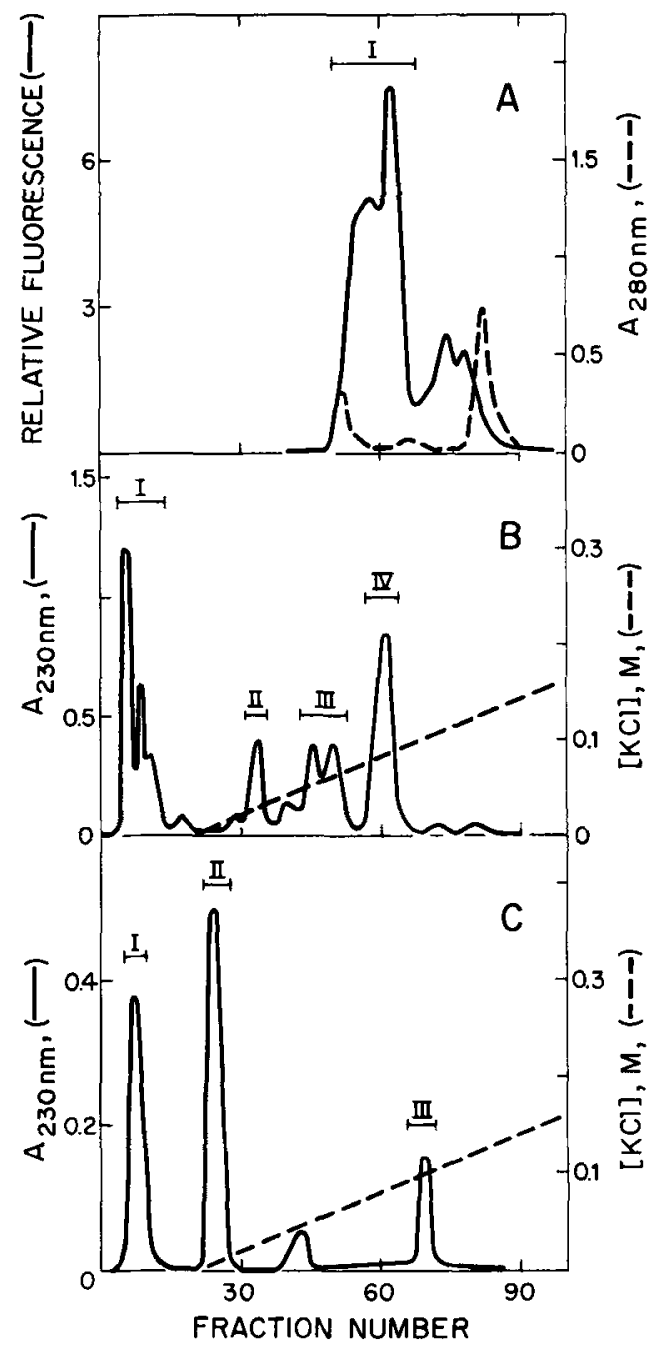

column of CM-52 cellulose. The elution profile for this column is shown in Figure 2C. Amino acid analyses and preliminary Edman degradation of pool I and pool II (Figure 2C) showed that the isolated fragments were pure and corresponded to peptide SP- 1 and SP-10, respectively. Since SP-1 consisting of 20 amino acids (Table II) corresponded to the known N-terminal sequence, this peptide was not analysed further. Pool III of the Figure 2B was a mixture of peptides, which were difficult to purify and thus the peptides in this pool were not analysed further.

Peptide SP-7 consisting of 28 amino acids (Table II) was degraded in the sequencer several times with only positive identifications of the first 10 residues. Addition of polybrene to the sequencer cup extended the identification to 18 residues. However, in two runs with polybrene using 150 and 200 nmoles of SP-7, the average repetitive yield for each step were only $73 \%$ and $80 \%$, respectively. For all runs the low average repetitive yields were due to a dramatic decrease in yield in step 6 (asparagine) after cleavage of threonine in step 5 (see below). This problem was overcome by isolation of the corresponding peptide SP-7 from performic acid oxidized SOD.

Figure 2. A. Separation of peptides from a Staphylococcus aureus protease digest of S-carboxymethylated SOD on a $2.5 \times 85 \mathrm{~cm}$ column of Sephadex G-25, superfine, equilibrated with $30 \%$ acetic acid. The peptides were eluted at a flow rate of $35 \mathrm{ml}$.hour ${ }^{-1}$ and fractions of $5.0 \mathrm{ml}$ were collected. Pool I was further fractionated on DE-52.

B. Rechromatography of pool I from (A) on a column $(1.6 \times 15 \mathrm{~cm})$ of DE-52 equilibrated with $0.01 \mathrm{~m}$ Tris- $\mathrm{HC1}, \mathrm{pH} 7.0$. The column was eluted at a flow rate of $30 \mathrm{ml} \cdot$ hour $^{-1}$ with a linear gradient of $0-0.2$ $\mathrm{M}-\mathrm{KCl}$ in $0.01 \mathrm{M}$-Tris- $\mathrm{HCl}, \mathrm{pH} 7.0$ as indicated in the figure. Fractions of $5.0 \mathrm{ml}$ were collected and pooled as indicated. Pool I was further fractionated on CM-52.

C. Rechromatography of pool I from (B) on a column $(1.6 \times 15 \mathrm{~cm})$ of CM-52 equilibrated with $0.01 \mathrm{~m}$ potassium phosphate $\mathrm{pH}$ 5.5. Elution was performed at a flow rate of $30 \mathrm{ml} \cdot$ hour $^{-1}$ with a linear gradient of the equilibration buffer containing 0 to $0.2 \mathrm{M}-\mathrm{KCl}$. Fractions of $5.0 \mathrm{ml}$ were collected and pooled as indicated. 
Table II

Amino acid composition of isolated $S$. aureus protease peptides

\begin{tabular}{lcccccc}
\hline & \multicolumn{2}{c}{ SP-7 } & \multicolumn{2}{c}{ SP-8 } & \multicolumn{2}{c}{ SP-10 } \\
\hline Amino acid & AAA $^{\text {a) }}$ & SEQ $^{\text {b) }}$ & AAA & SEQ & AAA & SEQ \\
\hline Aspartic acid & 3.8 & 4 & 4.4 & 3 & 2.0 & 2 \\
Threonine & 2.8 & 3 & 1.4 & 1 & 1.9 & 2 \\
Serine & 1.0 & 1 & 0.6 & 0 & 0.9 & 1 \\
Glutamic acid & 1.3 & 1 & 1.7 & 1 & 0 & 0 \\
Proline & 3.0 & 3 & 0.3 & 0 & 2.2 & 2 \\
Glycine & 3.8 & 4 & 3.4 & 2 & 3.9 & 4 \\
Alanine & 2.7 & 3 & 0.8 & 0 & 2.0 & 2 \\
Valine & 1.1 & 1 & 3.6 & 3 & 0.6 & 1 \\
Methionone & 0 & 0 & 1.0 & 1 & 0 & 0 \\
Isoleucine & 0.1 & 0 & 0.3 & 0 & 0.6 & 1 \\
Leucine & 0.1 & 0 & 0.2 & 0 & 2.1 & 2 \\
Tyrosine & 0 & 0 & 0 & 0 & 0 & 0 \\
Phenylalanine & 2.6 & 3 & 0.4 & 0 & 0 & 0 \\
Histidine & 2.1 & 2 & 1.0 & 1 & 0 & 0 \\
Lysine & 1.9 & 2 & 2.2 & 1 & 1.0 & 1 \\
Arginine & 0 & 0 & 0.9 & 1 & 1.0 & 1 \\
Half-cystinec) & 0.7 & $1^{\mathrm{d})}$ & 0 & 0 & 0.8 & 1 \\
Total number of residues & & 28 & & 14 & & 20 \\
Yield & $48 \%$ & & $18 \%$ & & $55 \%$ & \\
\hline
\end{tabular}

a) AAA is the amino acid composition from amino acid analysis. b) SEQ is the amino acid composition calculated from the sequence. c) Determined as S-carboxymethyl cysteine. d) Determined as cysteic acid. e) Calculated from the amount of SOD subjected to digestion.

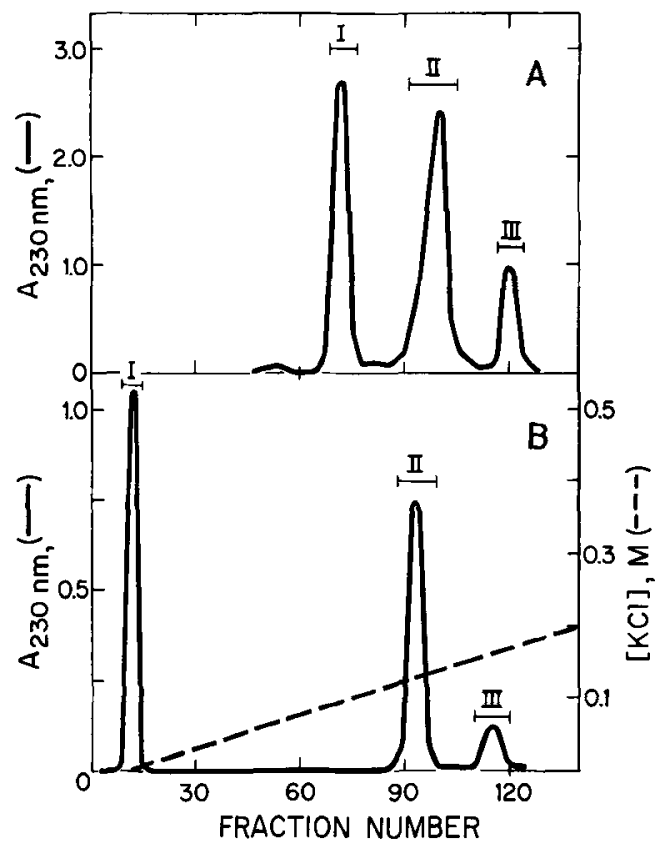

Figure 3. A. Separation of peptides from a Staphylococcus aureus protease digest of SOD on a $2.5 \times 85$ $\mathrm{cm}$ column of Sephadex G-50, superfine, equilibrated with $0.01 \mathrm{M}$-ammoniumbicarbonate $\mathrm{pH}$ 8.0. The column was eluted with the equilibration buffer at a flow rate of $30 \mathrm{ml} \cdot$ hour $^{-1}$ and fractions of $5.0 \mathrm{ml}$ were collected. Pool I containing the SP-7 and SP-10 peptide held together with the disulfide bond was then oxidized with performic acid (see Materials and Methods), and the peptides fractionated on DE-52.

B. Separation of peptides from pool I in (A) (after performic acid oxidation) on a $1.6 \times 30 \mathrm{~cm}$ column of $\mathrm{DE}-52$ equilibrated with $0.01 \mathrm{~m}-\mathrm{Tris}-\mathrm{HCl}, \mathrm{pH}$ 8.0 . The column was eluted at a flow rate of 40 $\mathrm{ml}$. hour ${ }^{-1}$ with a linear gradient of $\mathrm{KCl}$ from 0$0.25 \mathrm{M}$ in $0.01 \mathrm{M}$-Tris- $\mathrm{HCl}, \mathrm{pH} 8.0$ beginning of fraction 15 . Fractions of $5.0 \mathrm{ml}$ were collected and pooled as indicated by the horizontal bars. 
Following digestion of SOD by $\mathrm{S}$. aureus protease, as described for S-carboxymethyl SOD in section 2.6, the resulting peptide mixture was fractionated on a column of Sephadex G-50 as shown in Figure 3A. Amino acid analysis (not shown) of pool I indicated that it consisted of two peptides SP-7 and SP-10 held together by the single disulfide bond. After performic acid oxidation (17) the SP-7 and SP-10 peptides were separated by ion exchange chromatography on DE-52 cellulose (Figure 3B). Amino acid analyses of pool I and II showed that they corresponded to SP-10 and SP-7, respectively, and each contained a cysteic acid residue. Automated sequence analysis of the SP-7 peptide with cysteic acid in position 8 permitted identification of all 28 amino acid residues of the peptide. The average repetitive yield was $97 \%$, and the following sequence of SP-7 was established:

50 55

Phe-Gly-Asp-Ala-Thr-Asn-Gly-Cys-Val-Ser 60 65

-Ala-Gly-Pro-His-Phe-Asn-Pro-Phe-Lys

70
-Lys-Thr-His-Gly-Ala-Pro-Thr-Asp-Glu

Peptide SP-8 consisting of 14 amino acid residues (Table II) was also completely degraded in the sequencer with identification of all 14 residues. Starting with 100 nmoles of SP-8 the average repetitive yield was $85 \%$, and the following sequence found:

$\begin{array}{ccc}78 & 80 & 85 \\ \text { Val-Arg-His-Val-Gly-Asp-Met-Gly-Asn }\end{array}$ 90

-Val-Lys-Thr-Asp-Glu

Peptide SP-8 contains the single methionine residue in the total sequence and thus provides the overlap between $F_{N}$ and $F_{C}$.

Peptide SP-10 which consists of 20 amino acid residues (Table II) was sequenced twice in presence of polybrene using 300 nmoles of the peptide in each run, permitting the identification of the first 11 and 13 residues. The average repetitively yields were $83 \%$ and $88 \%$, and the following partial sequence of SP-10 was found:
134 140

Ser-Leu-Lys-Thr-Gly-Asp-Ala-Gly-Pro-Arg 145

-Pro-Ala-Cys (Gly 2, Ile, Val, Leu, Thr, Asn)

To gain additional sequence information on peptide SP-10 it was first reacted with dansyl chloride (see section 2.7) to block the N-terminal and lysyl $\varepsilon$-amino groups and subsequently cleaved with trypsin at Arg-143. Since the Nterminal group of SP-10 was blocked, the peptide mixture (300 nmoles) was applied directly to the sequencer and SP-10-T was degraded successfully for 7 cycles. The average repetitive yields was $80 \%$ and the following partial sequence of SP-10-T was established:

144 150

Pro-Ala-Cys-Gly-Val-Ile-Gly (Leu, Thr, Asn)

Thus the sequence of 17 of 20 residues of SP-10 was known. The sequence of the last three residues was obtained by carboxypeptidase- $Y$ digestion of SP-10. The time course of the release of free amino acids (Figure 4) is in agreement with the $\mathrm{C}$-terminal sequence

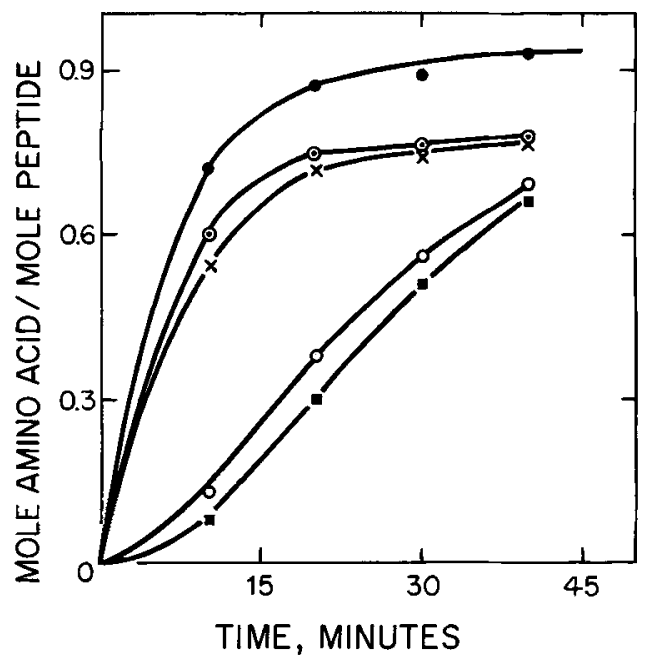

Figure 4. Rate of release of amino acids from peptide SP-10 by digestion with carboxypeptidase Y (see Materials and Methods for experimental details). The results suggest the $C$-terminal sequence of SP- 10 to be -Ile-Gly-Leu-Thr-Asn,

Asn (@), Thr (O), Leu (X), Gly (O) and Ile ( $(\boldsymbol{O})$. 
149

-Ile-Gly-Leu-Thr-Asn.

The -Ile-Gly- sequence provided the overlap to the previously determined partial sequence of SP-10-T. Furthermore, this C-terminal sequence is identical to the $\mathrm{C}$-terminal sequence of SOD itself, (see section 3.5) and thus demonstrated SP-10 to be the C-terminal fragment.

\subsection{Tryptic peptides of S-carboxymethylated SOD}

Peptides obtained by trypsin cleavage restricted to arginine sites of S-carboxymethylated and citraconylated SOD were fractionated on a Sephadex G-50 column as shown in Figure 5. Pools I to III were further purified by ion exchange chromatography on DE-52 cellulose as shown in Figure $6 \mathrm{~A}-\mathrm{C}$, respectively, Peak $\mathrm{V}$ in Figure 5 represents citraconic acid which absorbs at $230 \mathrm{~nm}$. Amino acid analyses of pools I and III in Figure 6A revealed that they both contained the same peptide, $\mathrm{T}-1$, and that the

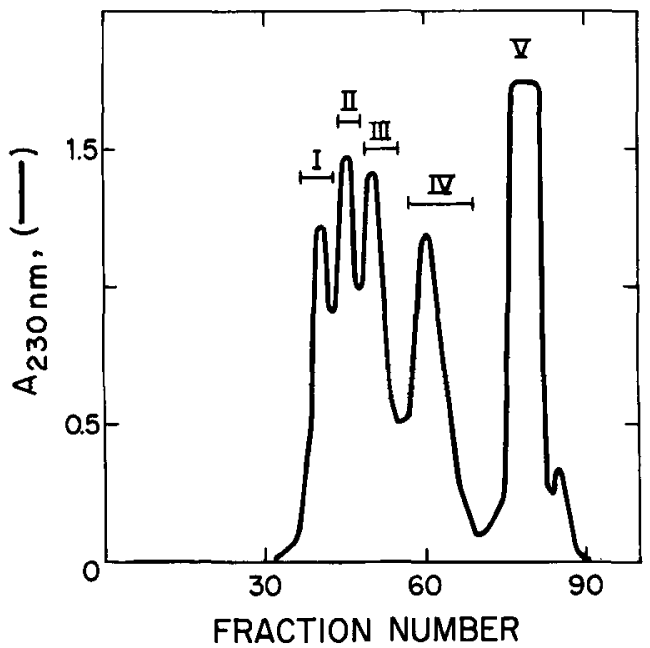

Figure 5. Chromatography of peptides from a tryptic digest of citraconylated, S-carboxymethylated SOD on a $2.5 \times 83 \mathrm{~cm}$ column of Sephadex G-50, fine, equilibrated with $0.01 \mathrm{M}-\mathrm{Tris}-\mathrm{HCl}, \mathrm{pH}$ 7.0. The column was eluted at a flow rate of $35 \mathrm{ml} \cdot$ hour $^{-1}$ and fractions of $5.0 \mathrm{ml}$ were collected. Pool I, II and III were further purified on DE-52 as shown in Figure $6 \mathrm{~A}, \mathrm{~B}$ and $\mathrm{C}$, respectively. amino acid composition (Table III) corresponded to the N-terminal peptide, residues $\mathrm{I}-43$, the sequence of which we previously have established (24). Furthermore, the only tyrosyl residue

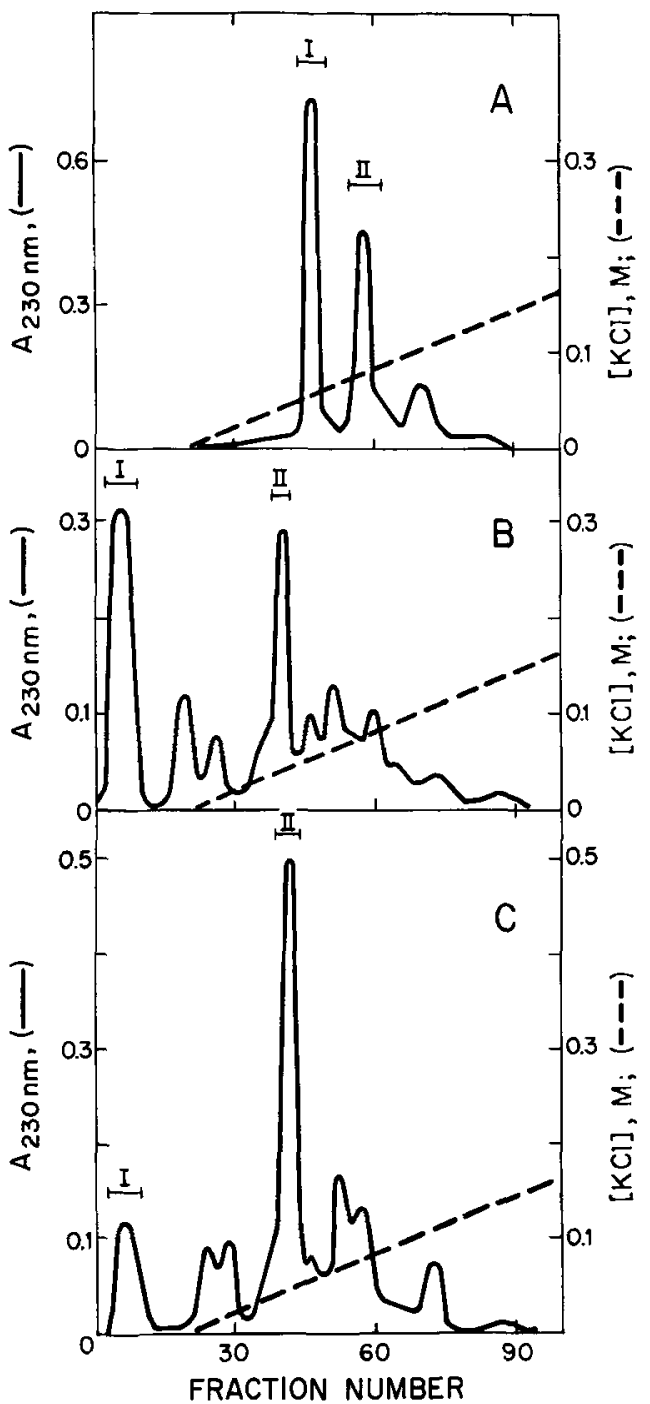

Figure 6. Separation of the peptides in pool I, II and III from Figure 5 on a $1.6 \times 16 \mathrm{~cm}$ column of DE-52 equilibrated with $0.01 \mathrm{~m}$-Tris-HC1, $\mathrm{pH} 7.0$. The column was eluted at a flow rate of $30 \mathrm{ml} \cdot$ hour $^{-1}$ with a linear gradient of $\mathrm{KCl}$ from $0-0.2 \mathrm{~m}$ in the equilibration buffer, as shown. Fractions of $5.0 \mathrm{ml}$ were collected and pooled as indicated.

A: Rechromatography of pool I in Figure 5. B: Rechromatography of pool II in Figure 5. C: Rechromatography of pool III in Figure 5. 


\section{Table III}

Amino acid composition of isolated tryptic peptides

\begin{tabular}{|c|c|c|c|c|c|c|c|c|}
\hline \multirow[b]{2}{*}{ Amino acid } & \multicolumn{2}{|c|}{$\mathrm{T}-1$} & \multicolumn{2}{|c|}{$\mathrm{T}-3$} & \multicolumn{2}{|c|}{$\mathrm{T}-4$} & \multicolumn{2}{|c|}{$\mathrm{T}-5$} \\
\hline & $\mathrm{AAA}^{\mathrm{a})}$ & $\mathrm{SEQ}^{\mathrm{b})}$ & AAA & SEQ & AAA & SEQ & AAA & SEQ \\
\hline Aspartic acid & 3.0 & 3 & 5.0 & 5 & 3.9 & 4 & 0.9 & 1 \\
\hline Threonine & 1.9 & 2 & 2.0 & 2 & 1.9 & 2 & 0.9 & 1 \\
\hline Serine & 4.0 & 5 & 2.7 & 3 & 1.8 & 2 & 0.5 & 0 \\
\hline Glutamic acid & 6.8 & 7 & 1.3 & 1 & 3.0 & 3 & 0.2 & 0 \\
\hline Proline & 1.8 & 2 & 1.0 & 1 & 1.0 & 1 & 0.8 & 1 \\
\hline Glycine & 4.0 & 4 & 5.9 & .6 & 4.8 & 5 & 2.2 & 2 \\
\hline Alanine & 5.4 & 6 & 1.3 & 1 & 2.0 & 2 & 0.9 & 1 \\
\hline Valine & 5.6 & 7 & 4.4 & 5 & 1.4 & 2 & 1.3 & 1 \\
\hline Methionine & 0 & 0 & 0.7 & 1 & 0 & 0 & 0.1 & 0 \\
\hline Isoleucine & 1.0 & 1 & 1.9 & 2 & 0.8 & 1 & 0.9 & 1 \\
\hline Leucine & 1.2 & 1 & 2.2 & 2 & 1.9 & 2 & I. I & 1 \\
\hline Tyrosine & 0.9 & 1 & 0 & 0 & 0 & 0 & 0 & 0 \\
\hline Phenylalanine & 1.0 & 1 & 0.9 & 1 & 0.2 & 0 & 0.1 & 0 \\
\hline Histidine & 0 & 0 & 0.9 & 1 & 1.0 & 1 & 0.3 & 0 \\
\hline Lysine & 1.9 & 2 & 3.9 & 4 & 2.0 & 2 & 0.5 & 0 \\
\hline Arginine & 0.9 & 1 & 0.9 & 1 & 0.9 & 1 & 0.3 & 0 \\
\hline Half-cystine ${ }^{c)}$ & 0 & 0 & 0 & 0 & 0 & 0 & 0.6 & 1 \\
\hline $\begin{array}{l}\text { Total number of } \\
\text { residues }\end{array}$ & & 43 & & 36 & & 28 & & 10 \\
\hline Yield $^{\mathrm{d})}$ & $33 \%$ & & $23 \%$ & & $28 \%$ & & $30 \%$ & \\
\hline
\end{tabular}

a) AAA is amino acid analysis. b) SEQ is the amino acid composition calculated from the sequence. c) Determined as S-carboxymethyl cysteine. ${ }^{d}$ ) Calculated from the amount of SOD subjected to tryptic digestion.

in the molecule was also located in this peptide (Table III). N-terminal analysis using the dansyl method gave valine, and treatment with carboxypeptidase B released only arginine as the Cterminal residue. Thus, it was confirmed that residue 43 was an arginine residue. The reason for the elution of $\mathrm{T}-1$ in two separate peaks in Figure $6 \mathrm{~A}$ is not clear. No further sequence analysis was performed on $\mathrm{T}-1$. Pools I and II in Figure $6 \mathrm{~B}$ were identified as $\mathrm{T}-3$ and $\mathrm{T}-1$, respectively. Since $T-3$ contains methionine (Table III) it provides the overlap between the $F_{N}$ and $\mathrm{F}_{\mathrm{C}}$ fragments. Peptide T-3 which consisted of 36 amino acids (Table III) was degraded in the sequencer, and the first 19 residues were identified. With 200 nmoles of $\mathrm{T}-3$, the average repetitive yield was $85 \%$ and the partial sequence was established as:

80

His-Val-Gly-Asp-Met-Gly-Asn-Val-Lys-Thr 90 95

-Asp-Glu-Asp-Gly-Val-Ala-Lys-Gly-Ser-
Carboxypeptidase $\mathrm{B}$ digestion of $\mathrm{T}-3$ released stoichiometric amounts of the expected arginine confirming position 115 as an arginine residue which was not conclusively determined in sequence analysis of $F_{C}$ (section 3.1). Pool $I$ and $\mathrm{II}$ in Figure $6 \mathrm{C}$ were identified as $\mathrm{T}-3$ and $\mathrm{T}-4$, respectively. Peptide T-4, consisting of 28 amino acids, was sequenced twice using 160 nmoles and 200 nmoles. The average repetitive yields were $91 \%$ and $90 \%$ respectively, and the partial sequence was as follows:

116 120 125

Ser-Val-Val-Ile-His-Ala-Gly-Gln-Asp-Asp 130 -Leu-Gly-Lys-Gly-Asp-Thr-Glu-Glu-Ser 135 -Leu-Lys-

After purification of pool IV (Figure 5) on DE-52 cellulose, amino acid analysis identified peptide $T-5$ in this fraction (Table III). However, since this peptide has already been sequenced as 
SP-10-T from the trypsin digestion of SP-10, $\mathrm{T}-5$ was not further analyzed.

Of the five possible tryptic peptides with Cterminal arginine only $\mathrm{T}-2$ was not found in any of the chromatograms (Figure 6A, B, C) as judged from amino acid analyses of the peptide containing fractions. Apparently, this peptide was very tightly bound to the ion exchange material. However, peptide $\mathrm{T}-2$ could be isolated from a tryptic digest of $F_{N}$. The $F_{N}$ fragment was citraconylated and digested with trypsin as described for SOD in section 2.7. The peptide

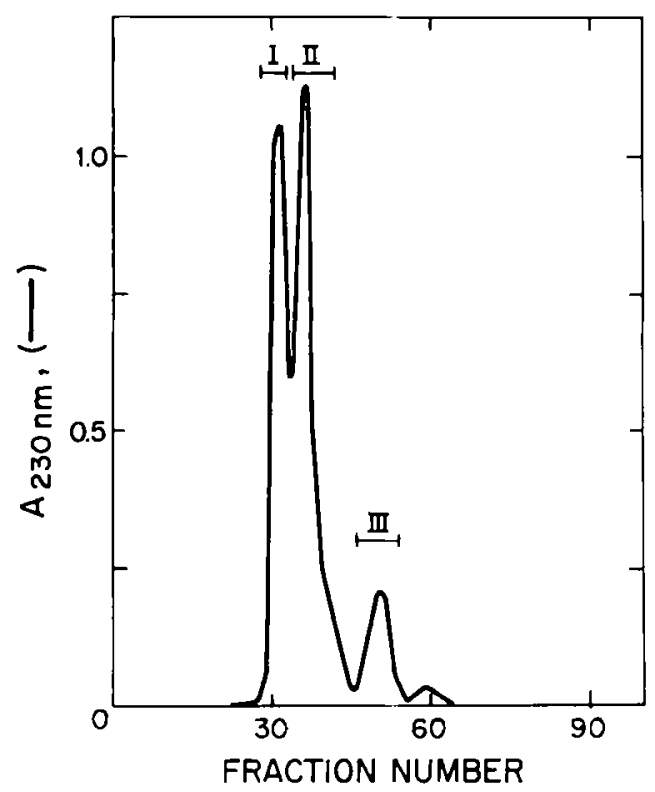

Figure 7. Fractionation of peptides from a tryptic digest of citraconylated $F_{N}$ on a $2.5 \times 85 \mathrm{~cm}$ column of Sephadex G-25, superfine, equilibrated with 0.01 M-ammoniumbicarbonate, $\mathrm{pH} 7.8$. The flow rate was $35 \mathrm{ml} \cdot$ hour $^{-1}$ and fractions of $5.5 \mathrm{ml}$ were collected and pooled as indicated.

mixture was then fractionated on a Sephadex G-25 column (Figure 7). A mino acid analysis of pool I and II showed that pool I contained predominantly peptide $\mathrm{T}-1$ with $15 \%$ peptide $\mathrm{T}-2$, whereas pool II contained predominantly $\mathrm{T}-2$ and $30 \% \mathrm{~T}-1$ in addition to another small peptide. Attempts to purify T-2 further were unsuccessful. Rechromatography on Sephadex G-25 did not improve the purity of the peptide, and chromatography on DE-52 or CM-52 cellulose again showed that this peptide (T-2) could not be eluted from the ion exchanges even under drastic conditions. Thus, the peptide mixture of pool II (Figure 7) was sequenced directly, and due to the quantitative determinations of the PTH-amino acids by HPLC, six cycles of Edman degradations were successfully performed, and the sequence of the first 6 residues of the three peptides were simultaneously identified. In addition to the $\mathrm{N}$-terminal sequence of $\mathrm{T}-1$, the $\mathrm{N}$-terminal part of $\mathrm{T}-2$ and the contaminating peptide were identified as follows:

44

T-2: Gly-Phe-His-Ile-His-Glu -

and the contaminating peptide:

$$
\begin{array}{lc}
68 & 73 \\
\text { Lys-Lys-Thr- ? -Gly-Ala- }
\end{array}
$$

This latter peptide seems to originate from a non-specific tryptic cleavage between residue $\mathrm{Phe}_{67}$ and Lys 68 , similar to a chymotryptic split (see section 3.4). Amino acid analysis of pool III showed that it contained the C-terminal tryptic peptide of $F_{\mathrm{N}}$ (His, Val, Gly. Asp).

\subsection{Chymotryptic peptides of \\ S-carboxymethylated SOD}

An overlapping peptide between the SP-7 and SP-8 peptides ( $\mathrm{Glu}_{7}-\mathrm{Val}_{78}$ ) was isolated from a limited chymotryptic digestion of S-carboxymethylated SOD (section 2.8.). The peptide mixture was chromatographed on a DE-52 ion exchange column. The peptide containing fractions were assessed for their amino acid composition. The possibility of a chymotryptic peptide containing methionine providing an overlap between SP-7 and SP-8 was explored by preliminary sequence analysis. Such a methionine containing peptide fraction was obtained. However, this fraction contained a second peptide which could not be removed under a variety of conditions. Despite this contamination the prior knowledge of the sequence of the peptide components as well as the ability of HPLC to quantitate the results facilitated the determination of the two sequences present. The peptide mixture was degraded in the sequencer twice, and in both runs the average 


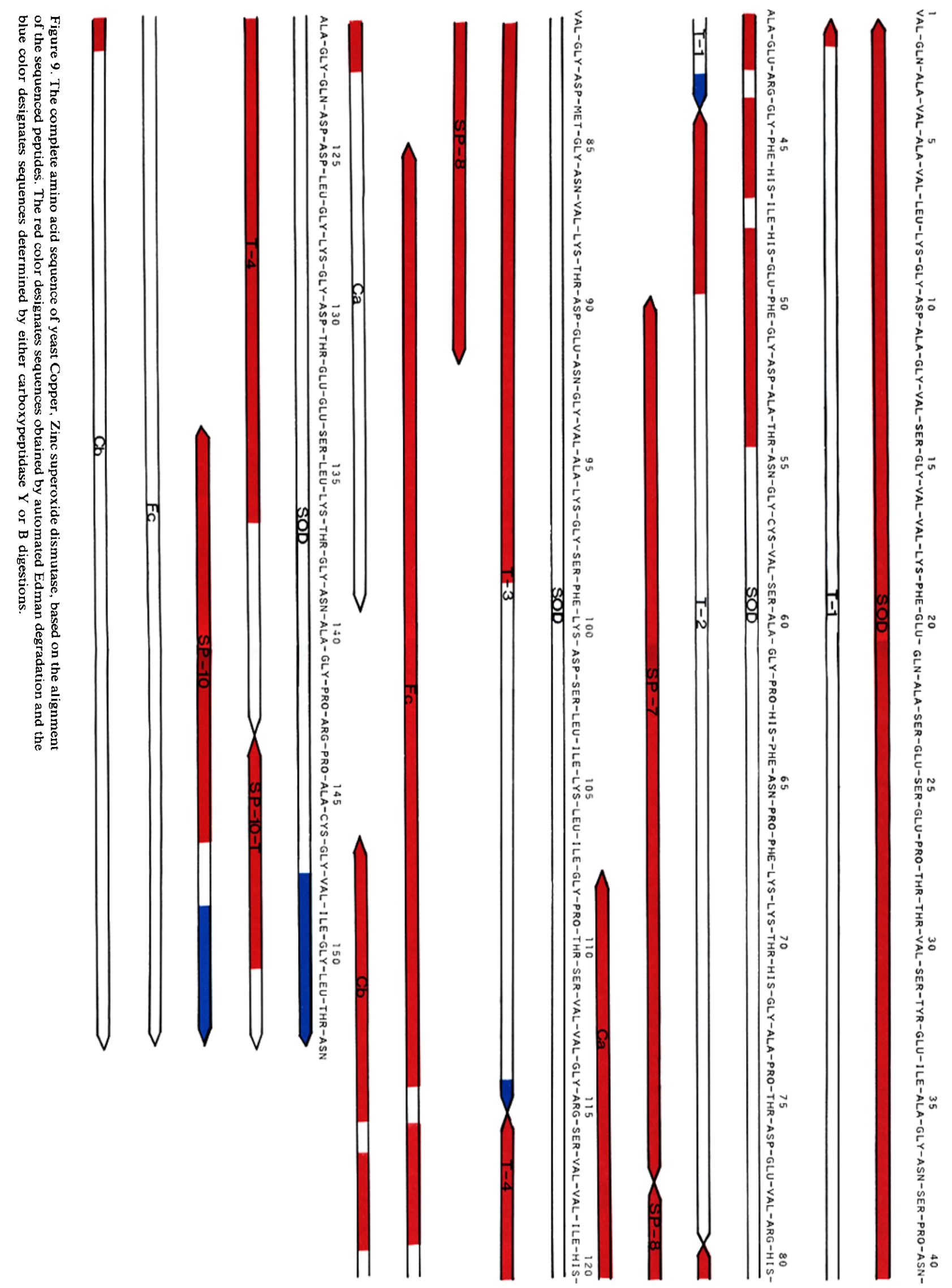


repetitive yield was $95 \%$ and the following two partial sequences were found:

$68 \quad 70 \quad 75$

C-a: Lys-Lys-Thr-His-Gly-Ala-Pro-Thr-Asp

-Glu-Val-Arg-His-Val-Gly-

107

110

115

C-b: Ile-Gly-Pro-Thr-Ser-Val-Val-Gly-Arg

121

$-?$-Val-Val-Ile-? - Ala-

Peptide $\mathrm{C}$-a provided the essential overlap between SP-7 and SP-8, whereas C-b confirmed sequences already determined for the $F_{C}$ and $T-4$ peptides.

\subsection{C-terminal sequence of}

\section{S-carboxymethylated SOD}

Digestion of S-carboxymethylated SOD with carboxypeptidase $\mathrm{Y}$ released asparagine, threonine, leucine, glycine, isoleucine, and valine. Analysis of the rate of release of these amino

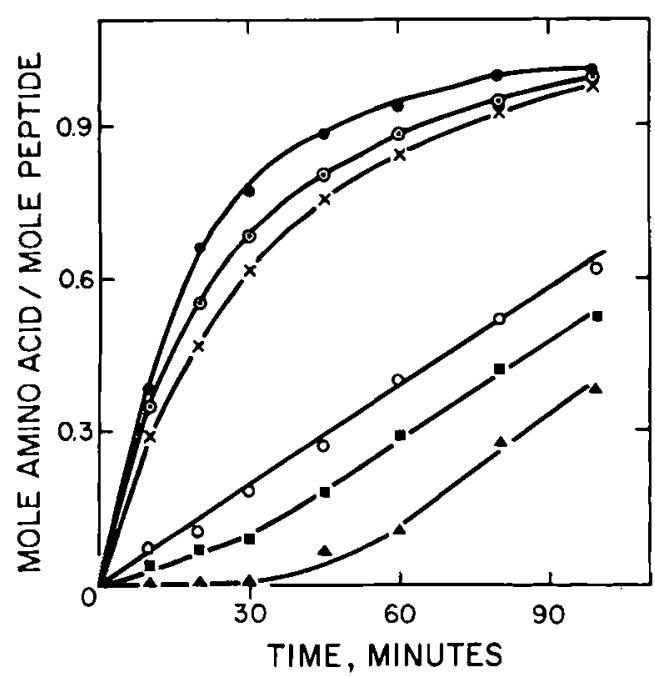

Figure 8. Rate of release of amino acids from Scarboxymethylated SOD by digestion with carboxypeptidase $Y$ (see Materials and Methods for experimental details). The results suggest the $\mathrm{C}$-terminal sequence of SOD to be $-\mathrm{Val}-\mathrm{Il}$ - Gly-Leu-Thr-Asn. Asn (@), Thr $(\odot)$, Leu $(\mathrm{X})$, Gly $(O)$, Ile $(\square)$ and $\mathrm{Val}$ $(\Delta)$. acids (Figure 8) established the C-terminal sequence as:

148

-Val-Ile-Gly-Leu-Thr-Asn

Digestion of S-carboxymethylated-SOD with carboxypeptidase A released only asparagine, threonine, and leucine. The $\mathrm{C}$-terminal sequence determined on the polypeptide chain is identical to the sequence deduced from C-terminal sequence determination on peptide SP-10 (see section 3.2.) and thus defines conclusively the $\mathrm{C}$ terminal sequence of the polypeptide chain.

\subsection{Alignment of peptides and complete amino acid sequence of SOD}

The reconstruction of the complete amino acid sequence from the isolated and sequenced peptides is summarized in Figure 9. Analysis of the native protein established 52 of the first 54 amino acid residues with gaps at position 43 and 47 (24). Amino acid analysis (Table III) and carboxypeptidase $\mathrm{B}$ digestion of $\mathrm{T}-1$ identified residue 43 as an arginine. Partial sequence analysis of $\mathrm{T}-2$ showed residue 47 to be isoleucine. The complete sequence analysis of SP-7 and SP-8 extended the structure to residue 91 , including methionine at position 84 , and thus provided an overlap between the cyanogen bromide peptides $F_{N}$ and $F_{C}$. The partial sequence determination of the chymotrypsin peptide $\mathrm{C}$-a provided the overlap between SP-7 and SP-8. The sequence analysis of $F_{C}$ extended the sequence through residue 119, with a gap at residue 115. Peptide T-3 also provided the overlap between $F_{N}$ and $F_{C}$ and confirmed in addition part of the SP-8 sequence. Carboxypeptidase $B$ digestion of T-3 identified directly residue 115 as an arginine. Analysis of $\mathrm{T}-4$ extended the sequence identification through residue 136. Peptide $\mathrm{C}-\mathrm{b}$ was the overlapping peptide between T-3 and T-4. Automated sequence analysis of SP-10 established the sequence through residue 147 . The last 7 residues were assigned from $\mathrm{N}$-terminal sequence degradation of SP-10-T and C-terminal sequence determination by carboxypeptidase $\mathrm{Y}$ digestion of either peptide SP-10 or the intact polypeptide chain of S-carboxymethylated SOD. Thus, the complete sequence was constructed entirely by 
direct sequence identification of all amino acid residues and of all peptide overlaps.

\subsection{Location of the disulphide bond}

The enzyme was found to contain 1.8 residues of cysteic acid per subunit after performic acid oxidation (Table I). Digestion of the SOD by S. aureus protease yielded upon fractionation on Sephadex G-50 (Figure 3A) peptide pool I which contained the two half-cystine residues. Subsequent performic acid oxidation and chromatography (Figure 3B) yielded two peptides. Amino acid analysis identified them as SP-10 and SP-7 respectively. Each contained one cysteic acid residue indicating the presence of a disulphide bridge between SP-7 and SP-10 (residues 57 and 146).

\section{DISCUSSION}

As mentioned earlier, the general strategy of the present sequence analysis was to use automated Edman degradation on large peptides. Information obtained using the native enzyme, the $\mathrm{F}_{\mathrm{C}}$ fragment and peptides generated by $\mathrm{S}$. aureus protease cleavage provided the basis for the sequence of 143 of the 153 amino acid residues. Analyses of selected tryptic and chymotryptic peptides provided the essential peptide overlaps and aided in the elucidation of the remaining 10 residues.

Unambiguous identification and location of the amino acid residues present in the protein was achieved from sequence analysis of fragments as depicted in Figure 9. It is evident that there is no difference between the amino acid composition obtained by this means or by amino acid analysis (Table I).

In general, the automated Edman degradation of large peptides exhibited stepwise yields ranging from 90 to $97 \%$. Furthermore, use of the inert carrier polybrene (29) greatly facilitated the sequence analysis of small peptides and in the case of SP-7 and SP-8 allowed the complete amino acid sequence to be determined. However, peptide SP-7, obtained from reduced and Scarboxymethylated SOD, either with or without polybrene could not be fully sequenced. This phenomenon, which was presumably due to cyclization of the Asn-Gly sequence (positions 6 and 7 in the peptide) manifested itself as a dramatic decrease in repetitive yield at step 6 .
Interestingly when SP-7 was obtained after performic acid oxidation of SP-7 and SP-10 from apo-SOD (section 3.2) the peptide could be sequenced to its $\mathrm{C}$-terminal with a repetitive yield of $97 \%$ in the presence of polybrene. Such cyclization of Asn-Gly and Asn-Ala sequences to their imide form has been documented (16). Although similar sequences occur at Asn 92Gly 93 and Asn $_{40}-\mathrm{Ala}_{41}$, we experienced no difficulties with these. This variation in the cyclization of Asn-Gly- and Asn-Ala sequences have been noted previously (16) and several factors seem to affect this cyclization reaction, such as the peptide purification procedure, the nature of the adjacent amino acid residues in the sequence and the sequenator program used (16).

Yeast-SOD is an enzyme made up of two identical subunits each comprised of 153 amino acid residues and each having a molecular weight of 15.950. Previously, the complete amino acid sequence of bovine erythrocyte $\mathrm{Cu}, \mathrm{Zn}-\mathrm{SOD}$ was reported. The current report contains the complete amino acid sequence of yeast $\mathrm{Cu}, \mathrm{Zn}-\mathrm{SOD}$. Availability of such information makes possible comparison between this enzyme and that of bovine origin. Figure 10 presents the amino acid sequences of both the yeast and bovine SOD aligned to provide the maximum degree of homology. Of the 151 amino acid residues found in the bovine enzyme 83 residues are conserved in the yeast enzyme, while another 45 residues are interconvertible by a single base change per DNA codon.

The essentiality of $\mathrm{Cu}$ and $\mathrm{Zn}$ for the activity of the enzyme has been documented (13). It is not surprising to find in the yeast enzyme that the six histidines and one aspartic acid known to participate as metal binding ligands in the bovine enzyme are conserved. This conservation of amino acid residues essential for metal binding has also been deduced from nuclear magnetic resonance experiments (6) and selective deuteration of the $\mathrm{C} 2$ protons in histidine residues (7) in both enzymes.

The high degree of sequence homology would appear indicative of similar three-dimensional structure, i.e. the 8-stranded barrel of antiparallel $\beta$-sheets with external loops around the metals (25). This suggested structure for the yeast enzyme facilitates the insertion of three additional residues between position 31 and 38 at the 


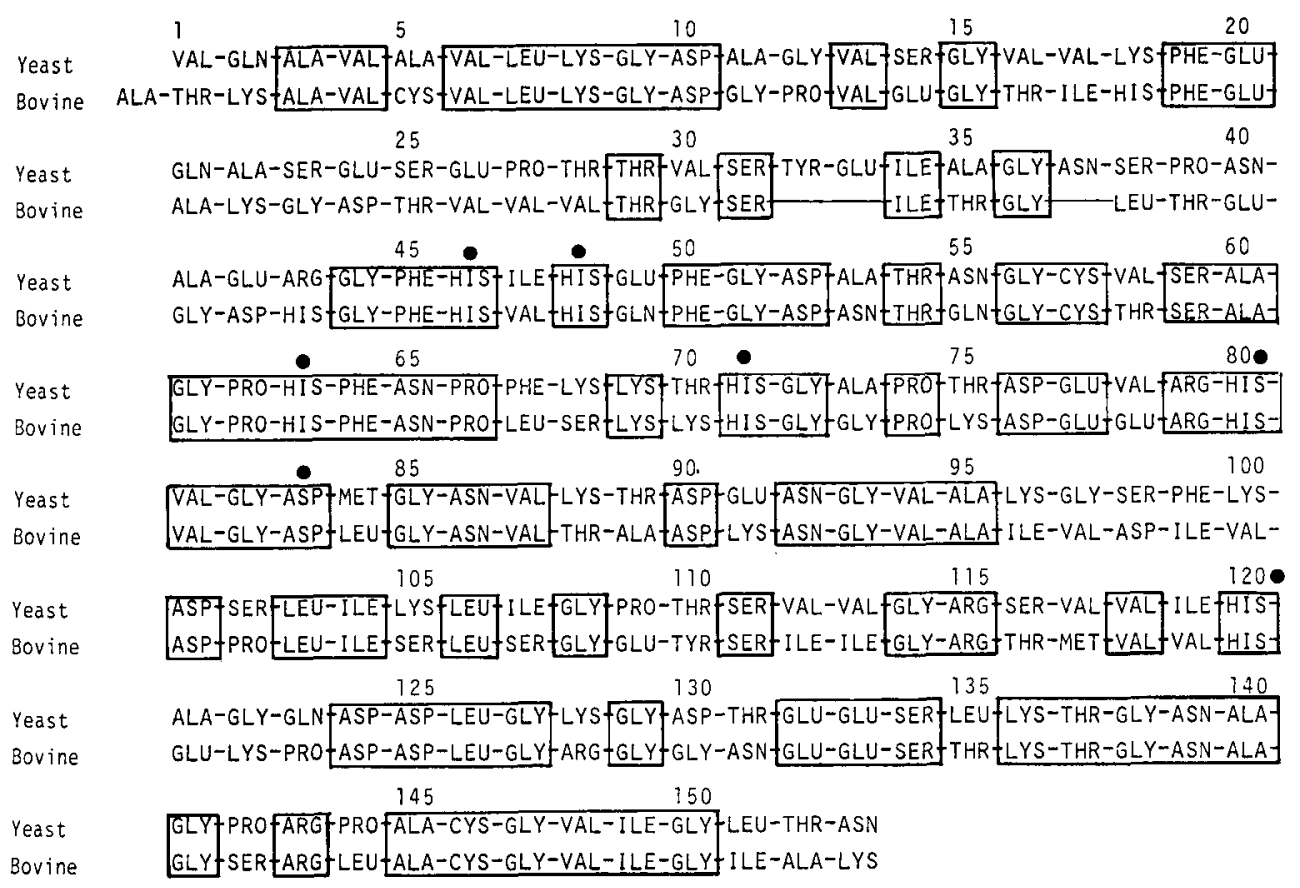

Figure 10. Comparison of the amino acid sequences of the Copper,Zinc superoxide dismutases from Saccharomyces cerevisiae and bovine erythrocytes. Gaps are introduced in the bovine enzyme to provide the greatest homology. The numbering system of the yeast enzyme has been adapted. Residues invariant in the two enzymes are enclosed in boxes. The metal ligands are also indicated $(\bullet)$.

end of one of the $\beta$-sheets. The single disulphide bond found in both enzymes is another conservation of amino acid sequence stabilizing the threedimensional structure. Furthermore, the dominance of hydrophilic residues in those regions known to form external loops in the bovine enzyme is likewise found in the yeast enzyme (residues 68-81 and 121-143). Similarly, the large content of glycine in the bovine enzyme ( 25 of 151 amino acid residues), known to be essential to the formation of the characteristic barrel structure (25), has also been found in the yeast enzyme ( 22 of 153 amino acid residues). Of the 22 glycine residues in the yeast enzyme 19 are in identical locations as in the bovine enzyme. Finally, the n.m.r. investigations indicate that not only are the metal ligands conserved in the yeast enzyme but also that the active site geometry is very similar to that of the bovine enzyme (6). It would therefore appear that the high degree of homology in the primary structure has manifested itself also in the threedimensional structure.
Comparing sequence data available from manganese- and iron-containing dismutases (15, 26) one finds a high degree of sequence homology in the amino-terminal regions of this family of enzymes. However, this homology is not shared with the $\mathrm{Cu}, \mathrm{Zn}$-SODs sequenced to date $(28,2)$, supporting the view that these two types of dismutases (Mn- and Fe-dismutases and $\mathrm{Cu}, \mathrm{Zn}$-dismutases) evolved independently of each other.

The remarkably high degree of homology (55\%) found in the two $\mathrm{Cu}, \mathrm{Zn}$-dismutases is similar to that found for cytochrome c $(62 \%)$ from the same two sources (8).

\section{ACKNOWLEDGEMENTS}

The authors wish to express their appreciation to professor MARTIN OTTESEN for helpful discussions during the course of this work. We also thank professor T. Viswanatha of the University of Waterloo, Waterloo, Canada for critical reading of the manuscript. V. HASEMANN, B. 
Martin and C. Overballe-Petersen would like to thank the board of the Carlsberg Laboratory for financial support. The excellent technical assistance of Lone Sørensen and Bodil CorneLIUSSEN is also gratefully acknowledged.

\section{REFERENCES}

1. Ambler, A. P.: Enzymatic hydrolysis with carboxypeptidase. Methods Enzymol. 25, 143154 (1972)

2. Barra, D., F. Martini, F. Bossa, G. Rotiluo, J. V. Bannister \& W. H. Bannister: Primary structure of human $\mathrm{Cu}, \mathrm{Zn}$ superoxide dismutase. Cysteine and tryptophan containing peptides. Biochem. Biophys. Res. Comm. 81, 1195-1200 (1978)

3. BeGg, G. \& F. J. Morgan: A non-volatile buffer with improved performance in automated protein sequencing. Febs Lett. 66, 243-245 (1976)

4. Benzon, J. R. \& P. E. Hare: O-phthalaldehyde: Fluorogenic detection of primary amines in the picomole range. Comparison with fluorescamine and ninhydrin. Proc. Nat. Acad. Sci. U.S.A., 72, 619-622 (1975)

5. Butler, P. J. G. \& B. S. Hartley: Maleylation of amino groups. Methods Enzymol. 25, 191199 (1972)

6. Cass, A. E. G., H. A. O. Hill, V. Hasemann \& J. T. JOHANSEN: ${ }^{1} \mathrm{H}$ nuclear magnetic resonance spectroscopy of yeast copper- zinc superoxide dismutase. Structural homology with the bovine enzyme. Carlsberg Res. Commun. 43, 439-449 (1978)

7. Cass, A. E. G., H. A. O. Hill, J. V. Bannister, W. H. Bannister, V. Hasemann \& J. T. JOHANSEN: The exchange of histidine $\mathrm{C} 2$ protons in superoxide dismutase. A novel method for assigning metal ligands in proteins. Biochem. $J$. (1979) in the press.

8. Dayнoff, M. O., ed.: Atlas of protein sequence and structure 1972. Volume 5. National Biomedical Research Foundation, Washington, D.C. (1972)

9. Dixon, H. B. F. \& R. N. Perham: Reversible blocking of amino groups with citraconic anhydride. Biochem. J. 109, 312-314 (1968)

10. Edman, P. \& G. BeGG; A protein sequenator, Eur. J. Biochem. 1, 80-91 (1967)

11. Edman, P.\& A. Henschen: Sequence determination In: Protein Sequence Determination. Molecular Biology Biochemistry and Biophysics 8 , 2nd edition, S. B. Needleman, ed., SpringerVerlag, Berlin, Heidelberg \& New York, pp. 232-279 (1975)
12. Fridovich, I.: Superoxide dismutases. Adv. Enzymol. 41, 35-97 (1974)

13. Fridovich, I.: Superoxide dismutases. Ann. Rev. Biochem. 44, 147-159 (1975)

14. Gold, A. M. \& D. F. Fahrney: Sulfonyl fluorides as inhibitors of esterases. II. Formation and reactions of phenylmethanesulfonyl-chymotrypsin. Biochenistry 3, 783-791 (1964)

15. Harris, J. I. \& H. M. Steinman: Amino acid sequence homologies among superoxide dismutases. In: Superoxide and Superoxide dismutases, A. M. Michelson, J. M. McCord and I. Fridovich, eds., Academic Press, London, New York and San Francisco, pp. 225-230 (1977)

16. Hermodson, M. A., L. H. Ericsson, K. Titani, H. Neurath \& K. A. Walsh: Application of sequenator analysis to the study of proteins. Biochemistry 11, 4493-4502 (1972)

17. Hirs, C. H. W., S. Moore \& W. H. Stein: Peptides obtained by tryptic hydrolysis of performic acid-oxidized ribonuclease. J. Biol. Chem. 219, 623-642 (1956)

18. HiRs, C. H. W.: Performic acid oxidation Methods Enzymol. 11, 197-199 (1967)

19. Hounard, J. \& G. R. Drapeau: Staphylococcal protease. A proteolytic enzyme specific for glutamoyl bonds. Proc. Nat. Acad. Sci. U.S.A. 69, 3506-3509 (1972)

20. KASPER, C. B.: Fragmentation of proteins for sequence studies and separation of peptide mixtures. In: Protein Sequence Determination. Molecular Biology and Biophysics 8, 2nd edition. S. B. Needleman, ed., Springer-Verlag, Berlin, Heidelberg and New York, pp. 114-161 (1975)

21. KULBE, K. D.: Micropolyamide thin-layer chromatography of phenylthiohydantoin amino acids (PTH) at subnanomolar level. A rapid microtechnique for simultaneous multisample identification after automated Edman degradations. Anal. Biochem. 59, 564-573 (1974)

22. Mendez, E. \& C. Y. LAI: Regeneration of amino acids from thiazolinones. Anal. Biochem. 68, 47-53 (1975)

23. Michelson, A. M., J. M. MCCORD \& I. Fridovich, eds.: Superoxide and superoxide dismutases. Academic Press, London, New York and San Francisco (1977)

24. Petersen, C., V. Hasemann, B. Martin, J. T. Johansen. I. Svendsen \& M. Ottosen: The amino terminal sequence of superoxide dismutase from Saccharomyces cerevisiae. Carlsberg Res. Commun. 42, 391-395 (1977)

25. Richardson, J. S., K. A. Thomas, B. H. Rubin \& D. C. RichaRdson: Crystal structure of bovine 
$\mathrm{Cu}, \mathrm{Zn}$ superoxide dismutase at $3 \AA$ resolution: Chain tracing and metal ligands. Proc. Nat. Acad. Sci., U.S.A., 72, 1349-1353 (1975)

26. Steinman, H. M.: The amino acid sequence of mangano superoxide dismutase from Escherichia coli B. J. Biol. Chem. 253, 8708-8720 (1978)

27. Steinman, H. M. \& R. L. Hill: Sequence homologies among bacterial and mitochondrial superoxide dismutases. Proc. Nat. Sci. U.S.A. 70, 3725-3729 (1973)

28. Steinman, H. M., V. R. Naik, J. L. Abernethy \& R. L. HILL: Bovine erythrocyte superoxide dismutase. Complete amino acid sequence. J. Biol. Chem. 249, 7326-7338 (1974)
29. Tarr, G. E., J. F. Beecher, M. Bell \& D. J. MCKean: Polyquarternary amines prevent peptide loss from sequenators: Anal. Biochem. 84 , 622-627(1978)

30. Waxdal, M. J., W. H. Konigsberg, W. L. Henley \& G. M. Edelman: The covalent structure of a human $\gamma$-G-immunoglobulin. II. Isolation and characterization of the cyanogen bromide fragments. Biochemistry 7, 1959-1966 (1968)

31. WoODS, K. R. \& K. T. WANG: Separation of dansyl amino acids by polyamide layer chromatography. Biochim. Biophys. Acta. 133, 369730 (1967) 